\title{
BIOMETHANE PRODUCTION BY LICENSED BRAZILIANS LANDFILLS AND POTENTIAL ENERGY USE IN MUNICIPALITIES
}

\section{PRODUÇÃO DE BIOMETANO POR ATERROS SANITÁRIOS LICENCIADOS BRASILEIROS E O USO DO POTENCIAL ENERGÉTICO EM MUNICIPIOS}

\author{
Érica Machado da Silva Guerreiroa, Bernardo Ornelas-Ferreira ${ }^{b}$, Elisabeth Ritter ${ }^{c}$ \\ ${ }^{a}$ São Paulo University, ${ }^{b}$ Municipal Urban Cleaning Company, ${ }^{C}$ Rio de Janeiro State University \\ ericamsguerreiro@gmail.com,ornelas.ambiental@gmail.com, ritterueri@gmail.com
}

Submissão: 06 de dezembro de 2021 Aceitação: 14 de dezembro de 2021

\section{Abstract}

One of the main challenges especially for small developing cities is to find economically viable alternatives to the management of municipal solid waste. This research aims to investigate the potential of biomethane production by licensed Brazilian landfills, to assess the feasibility of using biomethane energy in small municipalities. This study identified three biogas-upgrading facilities authorized by the Brazilian National Agency of Petroleum, Natural Gas and Biofuels (ANP) as to know: GNR Dois Arcos, Gás Verde and GNR Fortaleza. Field research collected additional information about the landfills and biomethane facilities investigated, to create indexes for supporting decision-makers in the waste management sector. Indexes $A$ and $B$ were proposed, which represent: the relation between the biogas production and the mass of landfilled municipal solid waste, and the relation between the biomethane processing capacity in the facility and the biogas production potential, respectively. This study showed that one of the facilities with lower biomethane production and biogas processing capacities, and which receives municipal solid waste from several small municipalities - such as GNR Dois Arcos - presented a similar value for index $A$ in relation to the biggest facility - such as Gás Verde - and the highest value for index $B$ compared to the other two larger facilities.

Key words: Municipal solid waste, landfill, biogas, biomethane, renewable energy.

\section{Resumo}

Um dos principais desafios, principalmente para as pequenas cidades em desenvolvimento, é encontrar alternativas economicamente viáveis para a gestão dos resíduos sólidos urbanos. Esta pesquisa tem como objetivo investigar o potencial de produção de biometano em aterros sanitários brasileiros licenciados, a fim de avaliar a viabilidade de uso de energia de biometano em pequenos municípios. Este estudo identificou três instalações de aproveitamento de biogás autorizadas pela Agência Nacional do Petróleo, Gás Natural e Biocombustíveis (ANP) a saber: GNR Dois Arcos, Gás Verde e GNR Fortaleza. A pesquisa de campo coletou informações adicionais sobre os aterros e instalações de biometano investigados, a fim de criar índices para apoiar os tomadores de decisão no setor de gestão de resíduos. Foram propostos os índices $A$ e $B$, que representam a relação entre a produção de biogás e a massa de resíduos sólidos urbanos depositados em aterro, e a relação entre a capacidade de processamento de biometano na instalação e o potencial de produção de biogás, respectivamente. Este estudo mostrou que uma das instalações com menor capacidade de produção de biometano e capacidade de processamento de biogas, que recebe resíduos sólidos urbanos de vários municípios 
de pequeno porte - como a GNR Dois Arcos - apresentou valor semelhante para o índice $A$ em relação à maior instalação - como Gás Verde - e o maior valor do índice $B$ em comparação com as outras duas instalações maiores.

Palavras-chave: Resíduo sólido municipal, aterro sanitário, biogás, biometano, energia renovável.

\section{INTRODUCTION}

According to the National System of Sanitation Information (SNIS, 2020) from Brazil, about 65.11 million tons of municipal solid waste (MSW) were collected in 2019 and approximately $75.1 \%$ was disposed at landfills. About $68 \%$ of Brazilian municipalities house less than 20 thousand inhabitants and the majority of MSW generated in Brazil (as expected for a developing country) is biodegradable, aroun $51 . \%$ is characterized as organic fraction of municipal solid waste (OFMSW) (Alfaia et al., 2017, Vieira et al., 2019).

The production of biogas in landfills occurs naturally from the anaerobic digestion of the OFMSW contained in the landfill's cells, promoted by anaerobic microorganism's consortia. Methane production in landfill depends mainly on: (i) MSW characteristics (such as composition, particle size, humidity, temperature and $\mathrm{pH}$ ) and (ii) operational landfilling techniques (Nascimento et al., 2019). Methane is the main greenhouse gas among the emissions caused by the final disposal of solid waste, with a global warming potential 28 times greater than carbon dioxide over a 100-year horizon (IPCC, 2014). In this way, biogas must be captured and burned to mitigate the GHG emissions into the atmosphere. Moreover, this methane can be recovered as energy and use as electricity and/or biomethane to replace fossil fuels and natural gas, enforcing the National Policy of Solid Waste (PNRS, 2016).

The energy use from OFMSW can be applied as an interesting alternative fuel in smaller regions and must be considered as an important sustainable local strategy (EPE, 2014, Adnan et al., 2019). The landfill's biogas can be used to produce heat, or even be converted into heat and electricity through a CHP (combined heat and power) generator (GIZ, 2019). Another possibility is the biogas upgrading into biomethane via its purification process, replacing fossil fuel and natural gas. The biogas upgrading necessarily implies the removal of $\mathrm{CO}_{2}$ in order to increase the methane content and the energy density of gas, and removal of $\mathrm{H}_{2} \mathrm{~S}$ and siloxanes which is harmful to engines and equipment (Petersson and Wellinger, 2009), Thrän et al., 2014, Hoo PY et al., 2018). According to Czyrnek-Delêtre et al. (2016), the mainly biogas upgrading Technologies are: membranes; adsorption (such as PSA - pressure swing adsorption); scrubbing (such as water, organic physical scrubbing and chemical scrubbing) and cryogenic (operated at low temperatures and high pressures). The final product is biomethane, whose methane concentration is above $90 \%$ (ANP, 2017).

According to EPA, the simplest and often most economical use of biomethane is as fuel for boilers, industrial processes and/or internal combustion engines (EPA, 2020). The biomethane as vehicle fuel or as renewable natural gas has being a sustainable and competitive alternative due to its high calorific potential. However, the ANP Resolution No. 685 (ANP, 2017) only regulated the guidelines for biomethane production in Brazil in 2017. Irena, 2018 points out gas grid injection as the most common and generally the most economical biomethane application when biomethane plant is close to the gas grid.

This research aims to investigate the potential of biomethane production by licensed Brazilian landfills and evaluate the viability of biomethane's energy use in municipalities.

\section{MATERIALS AND METHODS}

This study identified the authorized landfills biomethane facilities registered at the ANP standards and resolutions for biomethane's quality and production in Brazil (ANP No. 8/2015, ANP No. 685/2017 and ANP No. 734/2018). There are three biogas-upgrading facilities authorized by the ANP as to know: GNR Dois Arcos, Gás Verde (both located in Rio de Janeiro State, Southeast region) and GNR Fortaleza (located in Ceará State, Northeast region). 
Table 1 presents the landfills characterization.

Biomethane facilities information and data were collected based on: (i) Access to Information Act, Law No. 12527 (Brazil, 2011); (ii) public information at the ANP Electronic Information System, whose responsibility involves the regulation and authorization of biomethane producers; (iii) field investigation carried out at the biomethane facilities from landfills (GNR Dois Arcos and GNR Fortaleza).

Table 1. Characterization of landfills with biomethane production facilities

\begin{tabular}{|c|c|}
\hline Landfill & Characteristics \\
\hline \multicolumn{2}{|l|}{ Fortaleza's Landfill } \\
\hline Biomethane Facility & GNR Fortaleza \\
\hline MSW per day (tMSW/d) & 5,000 \\
\hline Population (citizens) & 3 millions \\
\hline Municipalities & Fortaleza and Caucaia \\
\hline Landfill Area $\left(\mathrm{m}^{2}\right)$ & $\begin{array}{l}1,230,000 \text { (old part) } \\
526,000 \text { (new part) }\end{array}$ \\
\hline \multicolumn{2}{|l|}{ Seropédica's Landfill } \\
\hline Biomethane Facility & Gás Verde \\
\hline MSW per day (tMSW/d) & 10,000 \\
\hline Population (citizens) & $7,053,808$ \\
\hline $\begin{array}{c}\text { Municipalities } \\
\text { Landfill Area }\left(\mathrm{m}^{2}\right)\end{array}$ & $\begin{array}{c}\text { Rio de Janeiro, Seropédica, Itaguaí, } \\
\text { Mangaratiba, São João de Meriti, Piraí and } \\
\text { Miguel Pereira } \\
3,000,000\end{array}$ \\
\hline \multicolumn{2}{|l|}{ Dois Arcos' Landfill } \\
\hline Biomethane Fcility & GNR Dois Arcos \\
\hline MSW per day (tMSW/d) & 762 \\
\hline Population (citizens) & 530,000 \\
\hline Municipalities & $\begin{array}{c}\text { São Pedro da Aldeia, Cabo Frio, Búzios, } \\
\text { Casimiro de Abreu, Silva Jardim, Araruama, } \\
\text { Iguaba Grande and Arraial do Cabo }\end{array}$ \\
\hline Landfill Area (m²) & 750 \\
\hline
\end{tabular}

Indexes A (Equation 1) and B (Equation 2) have been proposed in order to compare the biomethane facilities with different production capacities, which represents: $(A)$ biogas production per ton of landfilled $\operatorname{MSW}\left(\mathrm{m}^{3} \mathrm{t}^{-1}\right)$; (B) biomethane processing capacity per biogas production potential.

$$
\begin{aligned}
& \text { A index }=\frac{\text { biogas production }\left(\mathrm{m}^{3} d a y^{-1}\right)}{\text { landfilled MSW }\left(\mathrm{t} d a y^{-1}\right)} \\
& \text { B index }=\frac{\text { biomethane processing capacity }\left(\mathrm{m}^{3} \text { day }^{-1}\right)}{\text { biogas production }\left(\mathrm{m}^{3} \text { day }^{-1}\right)}
\end{aligned}
$$




\section{RESULTS}

Landfills Biomethane Production in Authorized

Facilities in Brazil

Table 2 shows the status of authorized biomethane facilities in Brazilian landfills, as biogas upgrading process, operational requirements, biogas processing capacity and biomethane production flow.

All three biomethane facilities hold a different biogas upgrading process: (i) GNR Fortaleza uses the physical absorption with organic solvent; (ii) Gás Verde uses the membrane separation and cryogenic processes; (iii) GNR Dois Arcos uses the water scrubbing process. GNR Fortaleza is the only biomethane producer authorized by ANP to inject gas into the grid (licensed in 2020), while Gás Verde and GNR Dois Arcos are licensed for gas transportation in cylinder trucks.
Commercial Purposes and Final Uses of Landfills Biomethane

In 2019, biomethane was used for the first time in a steel company in Brazil. The biomethane injected into the industry's complex pipeline has been applied for thermal use in the steel production process. Up to $72,000 \mathrm{~m}^{3}$ biomethane $\mathrm{d}^{-1}$ (renewable gas) from Seropédica's Landfill replaced about $30 \%$ of the consumption of natural gas (fossil energy source) used for heating (Ternium, 2019).

GNR Fortaleza injects biomethane into the natural gas grid. This biomethane is transported to the natural gas distribution centre via a $23 \mathrm{~km}$ gas pipeline (owned by the Natural Gas Company of Ceará State) and is used for cooking, heating and/or vehicle fuel (CEGÁS, 2018). Gás Verde compresses biomethane in cylinders and trades with local industries (heating) and gas stations (fuel), while GNR Dois Arcos compresses and sells biomethane to the gas stations.

Table 2. Biomethane facilities authorized by ANP in landfills

\begin{tabular}{cccccccc}
\hline Facitily & $\begin{array}{c}\text { MSW per } \\
\text { day }\left(\mathrm{t} \mathrm{day}{ }^{-1}\right)\end{array}$ & $\begin{array}{c}\text { Biogas } \\
\text { Processing } \\
\text { Capacity } \\
\left(\mathrm{m}^{3} \text { day }^{-1}\right)\end{array}$ & $\begin{array}{c}\text { Minimum } \\
\text { Biogas } \\
\text { Volume to } \\
\text { Operate }\left(\mathrm{m}^{3}\right)\end{array}$ & $\begin{array}{c}\text { Maximum } \\
\text { Capacity } \\
\left(\mathrm{Nm}^{3} \text { day }^{-1}\right)\end{array}$ & $\begin{array}{c}\text { Average } \\
\text { Capacity of } \\
\text { the System } \\
\left(\mathrm{Nm}^{3} \text { day }{ }^{-1}\right)\end{array}$ & $\begin{array}{c}\text { Biogas } \\
\text { Purification } \\
\text { Process }\end{array}$ & $\begin{array}{c}\text { Production } \\
\text { Flow }\end{array}$ \\
\hline $\begin{array}{c}\text { GNR } \\
\text { Fortaleza }\end{array}$ & 5,000 & 300,000 & 3,750 & 110,000 & $0-100,000$ & $\begin{array}{c}\text { Physical } \\
\text { Absorption with } \\
\text { Organic Solvent } \\
\text { Membrane }\end{array}$ & $\begin{array}{c}\text { Gas Grid } \\
\text { Injection }\end{array}$ \\
$\begin{array}{c}\text { Gás } \\
\text { Verde }\end{array}$ & 10,000 & 480,000 & $\begin{array}{c}\text { No } \\
\text { information }\end{array}$ & 204,000 & $0-150,000$ & $\begin{array}{c}\text { Separation and } \\
\text { Cryogenic }\end{array}$ & $\begin{array}{c}\text { Gas Cylinder } \\
\text { Transportation } \\
\text { by Truck }\end{array}$ \\
$\begin{array}{c}\text { GNR Dois } \\
\text { Arcos }\end{array}$ & 762 & 35,000 & 700,0 & 16,000 & $0-14,000$ & Water Scrubbing Transportation \\
by Truck
\end{tabular}

Comparison between Biomethane and Natural Gas Qualities

According to the ANP (ANP, 2017), the performance properties (Wobbe index - WI, high heating value $-\mathrm{HHV}$, and methane content $\left.-\% \mathrm{CH}_{4}\right)$ present different limits of values by region (North, Northeast and Southeast) according to the characteristics of the natural gas reservoirs. As biomethane is interchangeable with natural gas, the specifications must present such similarities.

The biomethane produced by GNR Fortaleza shows the highest HHV $\left(36,068.97 \mathrm{~kJ} \mathrm{~m}^{-3}\right)$, while the Gás Verde biomethane presents a slightly higher WI among the other producers $\left(47,379.43 \mathrm{~kJ} \mathrm{~m}^{-3}\right)$ and GNR Dois Arcos reached the highest methane content $\left(96.46 \% \mathrm{CH}_{4}\right)$.

Table 3 shows the content of $\mathrm{O}_{2}, \mathrm{CO}_{2}$ and $\mathrm{H}_{2} \mathrm{~S}$ 
in the biomethane produced in the studied landfills. The $\mathrm{O}_{2}$ content is higher in Gás Verde $\left(0.45 \% \mathrm{O}_{2}\right)$, as well as the percentage of $\mathrm{H}_{2} \mathrm{~S}\left(0.05 \mathrm{mg} \mathrm{m}^{-3}\right)$, even if in small quantities. GNR Fortaleza shows a higher percentage of $\mathrm{CO}_{2}\left(2.04 \% \mathrm{CO}_{2}\right)$. Table 3 also shows the values of siloxanes and halogenates present in the Brazilian biomethane facilities. It was observed that the halogen-chlorine content, whose highest value is present at GNR Dois Arcos, is related to the OFMSW. The halogen-fluorine present in GNR Dois Arcos, has its origin related to fluorinate water. Siloxanes, whose highest value is found at GNR Fortaleza, are present in a very small quantity due to the lower amount of products containing silicates (such as shampoos, conditioners and cleaning products - commonly found in the sewage, increasing the siloxane content into the biogas from wastewater treatment plants).
Viability of Biomethane Production in Landfills of Different Sizes

Table 4 shows the correlation between the mass of landfilled MSW and the biogas production in each landfill, represented by $A$ index and the correlation between the biogas processing and biomethane production capacities of each installation, shown by $B$ index. In all, GNR Fortaleza (which uses the physical absorption with organic solvent processes) presents the highest biogas yield (A index) among the studied facilities. Overall, GNR Dois Arcos (which uses the water scrubbing process) shows the highest $B$ index value (Table 4), despite presenting the lower biogas and biomethane production capacity, compared to the other two larger producers.

Table 3 - Biomethane`s quality certification in brazilian landfills

\begin{tabular}{|c|c|c|c|c|c|c|}
\hline \multicolumn{7}{|c|}{ Biomethane's Quality Certification Results } \\
\hline Facitily & $\begin{array}{c}\text { Oxygen } \\
\left(\mathrm{O}_{2} \% \mathrm{~mol}\right)\end{array}$ & $\begin{array}{c}\text { Carbon } \\
\text { Dioxide } \\
\left(\mathrm{CO}_{2} \% \mathrm{~mol}\right)\end{array}$ & $\begin{array}{l}\text { Sulfide Gas } \\
\left(\mathrm{mgH}_{2} \mathrm{~S} \mathrm{~m}^{-3}\right)\end{array}$ & $\begin{array}{l}\text { Siloxanes } \\
\left(\mathrm{mgSi} \mathrm{m}^{-3}\right)\end{array}$ & $\begin{array}{l}\text { Halogen- } \\
\text { Chlorine } \\
\left(\mathrm{mgCl} \mathrm{m}^{3}\right)\end{array}$ & $\begin{array}{l}\text { Halogen- } \\
\text { Flourine } \\
\left(\mathrm{mgF} \mathrm{m}^{-3}\right)\end{array}$ \\
\hline GNR Fortaleza & 0.06 & 2.04 & 0 & 0.09 & 0.42 & 0.04 \\
\hline $\begin{array}{l}\text { (Jan/19- } \\
\text { Mar/20) }\end{array}$ & $(0.02-0.63)$ & $(1.30-2.45)$ & $(0-0.07)$ & $(0.01-0.16)$ & $(0.16-0.51)$ & $(0-0.25)$ \\
\hline $\begin{array}{c}\text { Gás Verde } \\
\text { (Jun/19-Jun/20) }\end{array}$ & $\begin{array}{c}0.45 \\
(0.14-0.90)\end{array}$ & $\begin{array}{c}1.04 \\
(0-0.11)\end{array}$ & $\begin{array}{c}0 \\
(0-1.0)\end{array}$ & $\begin{array}{c}0.05 \\
(0.01-0.3)\end{array}$ & $\begin{array}{c}0.67 \\
(0.06-0.24)\end{array}$ & $\begin{array}{c}0.09 \\
(0-0.02)\end{array}$ \\
\hline $\begin{array}{c}\text { GNR Dois } \\
\text { Arcos }\end{array}$ & 0.38 & 1.04 & 0 & 0.05 & 0.67 & 0.09 \\
\hline $\begin{array}{l}\text { (Jan/19- } \\
\text { Mar/20) }\end{array}$ & $(0.03-0.80)$ & $(0.03-2.79)$ & $(0-0)$ & $(0-0.13)$ & $(0-3.01)$ & $(0-0.33)$ \\
\hline
\end{tabular}

Table 4 - Indexes A e B for each biomethane's facility quality certification in brazilian landfills

\begin{tabular}{lcccc}
\hline Facitily & $\begin{array}{c}\text { Landfilled MSW } \\
(\mathrm{t} \mathrm{day}-1)\end{array}$ & $\begin{array}{c}\text { Biogas Processing } \\
\text { Capacity }\left(\mathrm{m}^{3} \mathrm{~d}^{-1}\right)\end{array}$ & Index A $\left(\mathrm{m}^{3} \mathrm{~d}^{-1}\right)$ & Index B $\left(\mathrm{m}^{3} \mathrm{~m}^{-3}\right)$ \\
\hline GNR Fortaleza & 5,000 & 300,000 & 60 & 0.36 \\
Gás Verde & 10,000 & 480,000 & 48 & 0.31 \\
GNR Dois Arcos & 762 & 35,000 & 46 & 0.45 \\
\hline
\end{tabular}




\section{DISCUSSION}

Concerning Fortaleza's landfill, the intermediate researched size, shows the highest $A$ index, but an intermediate B index. According to Sun et al., 2015, physical absorption with organic solvent presents the efficiency range of $90.0-95.5 \%$ (adopted at GNR Fortaleza); water scrubbing range of $88.9-92.8 \%$ (GNR Dois Arcos), the membrane and cryogenic separation ranges from $82.4-98.0 \%$ and 84.9 . $96.7 \%$ respectively (adopted at Gás Verde).

Although GNR Fortaleza and GNR Dois Arcos adopted foreign technologies, their plant project planning was developed nationally. Both chose appropriate purification techniques according to their operation capacity, biogas yield and quality, in order to reach the biomethane requirements established by the ANP. Among several parameters, biogas diffuse losses and methane losses in biogas purification are the main factors affecting the total energy efficiency (Sun et al., 2015).

\section{CONCLUSIONS}

Biomethane's production from landfills in small municipalities is economically viable and achievable when the company operating the landfill and the biomethane producer act as partners allowing data transparency and the integration process from capture to final biogas purification stage. It was verified from indexes $A$ and $B$ proposed that biogas purification technologies presented different performances. It was possible to observe that a biomethane production facility with intermediate capacities for biogas processing and landfilled MSW presented an $A$ index with a higher value in relation to the other facilities, as well as the landfills with smaller and greater landfilled MSW showed similar values for $A$ index. It was also found that a facility, although with lower capacity for biomethane production and biogas processing receiving MSW from several small municipalities in the region, such as the GNR Dois Arcos, presented a higher B index compared to the other two larger producers. Another factor to be highlighted is that although foreign technologies are adopted it is very important that the facility project - especially in small landfills - is developed nationally in order to reduce operation and maintenance costs.

\section{ACKNOWLEDGEMENTS}

The authors are grateful to Brazilian National Agency of Petroleum, Natural Gas and Biofuels (ANP) for providing all data from biomethane facilities. We also acknowledge GNR Dois Arcos e GNR Fortaleza for allowing the field research.

\section{REFERENCES}

Adnan Al, ONG MY, Nomanbhay S, Chew KW, Show PL (2019) Technologies for Biogas Upgrading to Biomethane: A Review. Bioengineering 6(4): 92.

Alfaia RGSM, Costa AM and Campos JC (2017) Municipal solid waste in Brazil: A review. Waste Management \& Research 35: 1195 - 1209.

ANP (2017) Agência Nacional de Petróleo, Gás e Biocombustíveis. Resolução ANP No. 685 (in Portuguese) (accessed 10 May 2020).

Brazil (2011) Lei de Acesso à Informação. Lei No. 12.527 (in Portuguese).

CEGÁS (2018) Natural Gas Company of Ceará State. Avaiable at: <http://www.cegas.com.br/2018/04/> (accessed 28 July 2020).

Czyrnek-Delêter MM, Ahern EP and Murph JD (2016) Is small-scale upgrading of landfill gas to biomethane for use as a cellulosic transport biofuel economically viable? Biofuels, Bioproducts and Biorefining 10:139-149.

EPA (2020) LFG Energy Project Development Handbook. Landfill Methane Outreach Program. Environmental Protection Agency (accessed 10 May 2020).

EPE (2014) Empresa de Pesquisa Energética. Inventário Energético dos Resíduos Sólidos Urbanos. DEA 18/14 (in Portuguese) (accessed 10 May 2020).

Giz (2017) - Deutsche Gesellschaft für Internationale Zusammenarbeit. Waste-to-Energy Options in Municipal Solid Waste Management: A Guideline for Decision Makers in Emerging or Developing Countries (accessed 10 April 2020).

Hoo PY, Hashim H and Ho WS (2018) Opportunities and challenges: Landfill gas to biomethane injection into natural gas distribution grid through pipeline. Journal of Cleaner Production 175: 409-419. 
IPCC (2014) - Intergovernmental Panel on Climate Change. Climate Change 2014 Mitigation of Climate Change. Cambridge University Press (accessed 03 May 2020).

IRENA (2018) - The International Renewable Energy Agency. Biogas for Road Vehicles. Technology Brief (accessed 20 April 2020).

Nascimento MCB, Freire EP, Dantas FAZ and Giansante MB (2019) Estado da Arte dos Aterros de Resíduos Sólidos Urbanos que Aproveitam Biogás para Geração de Energia Elétrica e Biometano no Brasil. Engenharia Sanitária Ambiental: Vol. 24. 143 - 155 (in Portuguese).

Petersson, A and Wellinger A (2009) Biogas Upgrading Technologies - Developments and Innovations. Task 37 Energy from biogas and landfill gas. IEA (International Energy Agency) Bioenergy (accessed 12 April 2020).

Vieira, Vham and Matheus DR (2019) Environmental assessments of biological treatments of biowaste in life cycle perspective: A critical review. Waste Management and Research 37: 1183-1198.
PNRS (2010). Política Nacional de Resíduos Sólidos. Law No. 12,305 (in Portuguese) (accessed 03 May 2020).

SNIS (2020). National System of Sanitation Information. Sistema Nacional de Informações sobre Saneamento (in Portuguese).

Sun Q, Li H, Yan J, Liu L, Yu Z and Yu X (2015) Selection of Appropriate Biogas Upgrading Technology - A Review of Biogas Cleaning, Upgrading and Utilisation. Renewable and Sustainable Energy Reviews 51: 521-532.

Ternium (2019) Avaiable at: <https://br.ternium.com/pt/novidades/noticias/ biometanona-siderurgia--17096859519> (accessed 05 May 2020).

Thrän et al. (2014) Biomethane - status and factors affecting market development and trade. Task 40 and Task 37 Joint Study. IEA (International Energy Agency) (accessed 03 May 2020). 